\title{
Bone mass in patients with rheumatoid arthritis
}

\author{
Roland F J M Laan, Piet L C M van Riel, Levinus B A van de Putte
}

Low bone mass is a frequent abnormality in patients with rheumatoid arthritis (RA) and may relate to the disease in different ways. Firstly, localised, juxta-articular bone loss is a common phenomenon and may be directly related to joint inflammation. Secondly, generalised bone loss has been suggested as an extra-articular manifestation of RA, and several factors, including disease activity and reduced mobility, have been implicated in its pathogenesis. Finally, patients with RA are treated with a variety of agents that may affect bone mass, including glucocorticoids. However, whether low dose glucocorticoid treatment contributes to generalised osteoporosis in patients with RA is a matter of debate. Some have suggested that positive influences on disease activity and mobility may outweigh their deleterious effects on bone..$^{1-7}$

In this review we will focus on the association between generalised osteoporosis and RA, and on the effects of low dose glucocorticoid treatment on bone mass in these patients, including data that have been presented at recent scientific meetings. Abnormalities in bone metabolism and calcium regulating hormones, or strategies for the management of osteoporosis in patients with RA, are not included. These topics have been reviewed recently elsewhere..$^{1-356}$

Before discussing currently available data we would like to mention some special problems related to bone mass measurements and to the design of studies dealing with bone mass in patients with RA.

\section{Special problems in methodology} BONE MASS MEASUREMENTS

At a recent consensus development conference osteoporosis was defined as 'a disease characterised by low bone mass, microarchitectural deterioration of bone tissue leading to enhanced bone fragility, and a consequent increase in fracture risk'. ${ }^{8}$
Low bone mass is thus an essential feature of osteoporosis, and over the past two decades new non-invasive methods for its measurement have been developed. Those that have been used in patients with RA include neutron activation analysis, single photon absorptiometry, dual photon absorptiometry, dual energy $x$ ray absorptiometry, and quantitative computed tomography. The characteristics of these methods have been extensively reviewed elsewhere, and are summarised in table 1. ${ }^{9-12}$ The appropriateness of peripheral bone mass measurements by single photon absorptiometry in the distal radius of patients with RA has been debated. It is generally accepted that the correlation between bone mass measurements at appendicular and axial sites is poor to moderate at best, both in normal subjects and in patients with osteopenic bone diseases. ${ }^{1314}$ In addition, it has been suggested that in patients with RA, measurements in the distal forearm might also be affected by the inflammatory process in the adjacent wrist, and thereby reflect juxta-articular instead of generalised osteoporosis. ${ }^{16}$ Existing data do not support this view, however, as measurements in the distal radius are not affected by the degree of radiological wrist destruction. ${ }^{15-17}$

Measurements of total body bone mass should also be interpreted cautiously as juxtaarticular and generalised bone loss cannot, of course, be separated with these methods. Low bone mass, as measured by different techniques at different sites, was shown to be associated with an increased risk of fractures in many studies. In general, a decrease in bone mass of one standard deviation is associated with an increase in future fracture risk of $50-100 \% .^{12} 18$ Other factors, probably related to bone quality, may also partly determine fracture risk. In a recent prospective study, for example, reduced bone mass and existing vertebral fractures were strong independent predictors of future vertebral fractures. ${ }^{19}$ In patients with RA, or with gluco-
Department of Rheumatology, University Hospital Nijmegen, PO Box 9101 6500 HB Nijmegen, The Netherlands R F J M Laan P L C $M$ van Riel L B A van de Putte Correspondence to: Dr Laan.
Table 1 Characteristics of methods for measurement of bone mass, adapted from several sources ${ }^{9-12}$

\begin{tabular}{|c|c|c|c|c|c|}
\hline Characteristic & $N A^{*}$ & $S P A^{*}$ & $D P A^{*}$ & $D X A^{*}$ & $Q C T^{*}$ \\
\hline \multirow[t]{2}{*}{ Site } & Total body & Radius & $\begin{array}{l}\text { Spine } \\
\text { Hip } \\
\text { Total body }\end{array}$ & $\begin{array}{l}\text { Spine } \\
\text { Hip } \\
\text { Total body }\end{array}$ & Spine \\
\hline & Integral & Integral & Integral & Integral & $\begin{array}{l}\text { Trabecular } \\
\text { Cortical }\end{array}$ \\
\hline $\begin{array}{l}\text { Precision }(\%) \dagger \\
\text { Accuracy }(\%) \ddagger \\
\text { Radiation dose }(\mathrm{mJ} / \mathrm{kg})\end{array}$ & $\begin{array}{l}2-5 \\
5-10 \\
20-50\end{array}$ & $\begin{array}{l}1-2 \\
5 \\
0 \cdot 05-0 \cdot 1\end{array}$ & $\begin{array}{l}2-4 \\
5-10 \\
0 \cdot 05\end{array}$ & $\begin{array}{l}1-2 \\
4-8 \\
0.01-0.03\end{array}$ & $\begin{array}{l}2-5 \\
5-20 \\
1-4\end{array}$ \\
\hline
\end{tabular}

${ }^{*} \mathrm{NA}=$ neutron activation analysis: $\mathrm{SPA}=$ single photon absorptiometry; DPA=dual photon absorptiometry; DXA=dual energy $x$ ray absorptiometry; QCT = quantitative computed tomography.

†Precision is defined as the coefficient of variation for repeated measurements.

¥Accuracy is defined as the coefficient of variation between the result of the measurement involved and that of a reference method (for example measurement of ashed weight). 
corticoid induced osteoporosis, the relation between bone mass and fracture risk has not been studied extensively. Some reports have suggested, however, that in these conditions bone loss is associated mainly with trabecular thinning and that bone microarchitecture-and thus perhaps also bone strength-may be relatively preserved. ${ }^{20} 21$

\section{STUDY DESIGNS}

Most studies of bone mass in RA published so far have had cross sectional designs. Mean bone mass in rheumatoid patients without glucocorticoid treatment is compared with mean bone mass in a normal control group, or with mean bone mass in patients with $\mathrm{RA}$ receiving long term glucocorticoid treatment, or with both. Bone mass is measured only once, and information about possible determinants, such as disease duration, disease activity, functional capacity, and glucocorticoid treatment, is collected at the same time.

When interpreting these studies one has to take into account the broad range of bone mass in normal subjects. In consequence it is difficult to be certain that differences found between groups are caused by either the disease or its treatment. To minimise the risk of misinterpretation one should at least be informed about the distribution of known risk factors for osteoporosis. Bone mass decreases with age, is lower in women than in men, and varies also with race, genetic background, menopausal state, body build, dietary factors, the level of physical activity, alcohol consumption, and cigarette smoking. Bone mass may also be affected by some medical conditions, such as insulin dependent diabetes mellitus, hyperthyroidism, hyperparathyroidism, and Cushing's syndrome. ${ }^{22}$

Another problem in cross sectional studies is that the severity of the disease varies during the course of the RA. If a diminished bone mass is found only in those patients who, at the moment of measurement, have a low level of physical activity it is tempting to conclude that that may be the most important factor in the pathogenesis of osteoporosis in these patients. One can, however, not exclude the possibility that the past disease activity caused both the osteoporosis and the functional disability, although the measured disease activity at the moment of study may be the same in patients with and without severe functional impairment.

Prospective studies, which have been scarce until now, offer the possibility of baseline and follow up bone mass measurements, and of regular evaluations of possibly important determinants, such as disease activity and functional capacity. It has been suggested that deleterious effects on bone are present predominantly early in the course of the disease or of glucocorticoid treatment. ${ }^{23-25}$ If bone mass measurements are properly timed, prospective studies allow for the further evaluation of these hypotheses.

An important issue is whether low dose prednisone treatment causes osteoporosis in patients with RA. Study of this problem is seriously hampered by the possibility of selection bias in non-randomised studies. Glucocorticoid treatment is started mostly because the patient has a severe, active disease with concomitant functional disability. Decreases in bone mass noted after the start of such treatment may well be the consequence of the condition of the patient and not of glucocorticoid therapy. This problem can only be solved if the decision to start glucocorticoid treatment is left to chance in a randomised trial.

\section{Bone mass in patients with RA}

Studies of bone mass in patients with RA focus on bone loss as an extra-articular manifestation of RA, or on the effects of corticosteroid treatment. Many published reports have considered both issues at the same time. For this review we have attempted to separate them as much as possible. In the next paragraph we discuss more extensively some factors that have been suggested as determinants of bone loss in patients with RA. Results of studies have often been contradictory. Discrepancies may in part be due to differences in methods for bone mass measurement and to different study designs, as was discussed above.

\section{CROSS SECTIONAL STUDIES}

Tables 2 and 3 summarise the results of cross sectional studies of bone mass in RA for patients without and with glucocorticoid treatment respectively. ${ }^{15-17}$ 27-32 Confidence intervals reported in the tables were calculated from tables or graphs. Reports not allowing calculation of $\mathbf{9 5 \%}$ confidence intervals are not included in the tables, but are discussed below.

Sambrook et al studied lumbar and femoral bone mass by dual photon absorptiometry in 12 glucocorticoid treated and 15 untreated male patients with RA. The mean daily prednisone dose was $10.3 \mathrm{mg}$ in those patients. The study also included 20 normal male controls. Bone mass was significantly decreased in the patients with RA compared with the normal controls. The patients treated with prednisone had a significantly lower bone mass than those without glucocorticoid treatment. ${ }^{33} \mathrm{O}^{\prime}$ Malley et al studied axial bone mass in 75 patients with RA by dual photon absorptiometry and dual energy $x$ ray absorptiometry. ${ }^{34}$ An unspecified number of their patients were treated with glucocorticoids. Details about dosage and duration of prednisone treatment were not given. Bone mass was measured in the lumbar spine and the femur. Mean bone mass in patients was significantly lower than in healthy controls, and varied between 74.0 and $95 \cdot 2 \%$ of normal in the different regions. No differences were found between the glucocorticoid treated and untreated patients. ${ }^{34}$

At recent scientific meetings further cross sectional studies were presented that had evaluated axial bone mass by dual energy $x$ ray absorptiometry. Eggelmeijer et al measured lumbar bone mass in 45 non-steroid treated, ambulant patients with RA. Mean bone mass was $101 \cdot 1 \%$ of normal. ${ }^{35}$ Hall et al found a small 
Table 2 Bone mass in non-glucocorticoid treated patients with rheumatoid arthritis: cross sectional studies

\begin{tabular}{|c|c|c|c|c|c|c|c|c|}
\hline \multirow[t]{3}{*}{ Ref } & \multirow{3}{*}{$\begin{array}{l}\text { Number } \\
\text { (women:men) }\end{array}$} & \multicolumn{3}{|c|}{ Patient characteristics } & \multicolumn{4}{|l|}{ Bone mass } \\
\hline & & \multirow{2}{*}{$\begin{array}{l}\text { Age } \\
\text { (years) }\end{array}$} & \multirow{2}{*}{$\begin{array}{l}\text { Duration of } \\
R A \text { (years) }\end{array}$} & \multirow{2}{*}{$\begin{array}{l}\text { Functional } \\
\text { capacity }(F C)\end{array}$} & \multirow[t]{2}{*}{ Methodt } & \multirow[t]{2}{*}{ Site } & \multicolumn{2}{|c|}{ Results (percentage of normal) } \\
\hline & & & & & & & Mean & $95 \%$ CI limits \\
\hline 26 & $34: 21$ & 49 & $2 \cdot 9$ & $1 \cdot 7$ & SPA & $\begin{array}{l}\text { Radius, proximal } \\
\text { Radius, distal }\end{array}$ & $\begin{array}{l}93 \\
90\end{array}$ & $\begin{array}{l}88 \text { to } 98 \\
85 \text { to } 95\end{array}$ \\
\hline 27 & $34: 29$ & $\begin{array}{l}\text { Women: } 52 \cdot 4 \\
\text { Men: } 51 \cdot 7\end{array}$ & $\begin{array}{l}\text { Women: } 8 \cdot 2 \\
\text { Men: } 8 \cdot 5\end{array}$ & $\begin{array}{l}\text { Women: } 1 \cdot 99 \\
\text { Men: } 2 \cdot 14\end{array}$ & NA & Total body & $\begin{array}{l}\text { Women: } 94 \\
\text { Men: } 95\end{array}$ & $\begin{array}{l}90 \text { to } 98 \\
91 \text { to } 99\end{array}$ \\
\hline 15 & $33: 28$ & $51 \cdot 5$ & $7 \cdot 7$ & Not available & SPA & $\begin{array}{l}\text { Radius, proximal } \\
\text { Radius, distal }\end{array}$ & $\begin{array}{l}95 \cdot 6 \\
92 \cdot 9\end{array}$ & $\begin{array}{l}92 \cdot 0 \text { to } 99 \cdot 2 \\
88 \cdot 3 \text { to } 97 \cdot 5\end{array}$ \\
\hline 23 & $76: 29$ & $53 \cdot 0$ & $\begin{array}{l}\text { FC I: } 7 \cdot 6 \\
\text { FC II: } 10 \cdot 2 \\
\text { FC III/IV: } 12 \cdot 3\end{array}$ & $\begin{array}{l}\text { I: } n=37 \\
\text { II: } n=50 \\
\text { III } / I V: n=18\end{array}$ & SPA & Radius, distal & $\begin{array}{l}\text { FC I: } 92 \\
\text { FC II: } 86 \\
\text { FC III/IV: } 79\end{array}$ & $\begin{array}{l}88 \text { to } 96 \\
82 \text { to } 90 \\
74 \text { to } 84\end{array}$ \\
\hline 28 & $36: 0$ & $59 \cdot 2$ & $6 \cdot 2$ & $\begin{array}{l}\text { II: } n=22 \\
\text { III: } n=14\end{array}$ & $\begin{array}{l}\text { SPA } \\
\text { DPA }\end{array}$ & $\begin{array}{l}\text { Radius, proximal } \\
\text { Radius, distal } \\
\text { Spine }\end{array}$ & $\begin{array}{l}84 \cdot 4 \\
87 \cdot 2 \\
109 \cdot 4\end{array}$ & $\begin{array}{l}78 \cdot 3 \text { to } 90 \cdot 5 \\
81 \cdot 6 \text { to } 92 \cdot 8 \\
102 \cdot 0 \text { to } 116 \cdot 8\end{array}$ \\
\hline 29 & $40: 0$ & $55 \cdot 8$ & $11 \cdot 8$ & $\begin{array}{l}\text { I: } \mathbf{n = 1 5} \\
\text { II: } \mathbf{n = 2 2} \\
\text { III: } \mathbf{n = 3}\end{array}$ & DPA & $\begin{array}{l}\text { Spine } \\
\text { Femoral neck }\end{array}$ & $\begin{array}{l}\text { Premenopausal: } 95 \cdot 0 \\
\text { Postmenopausal: } 91 \cdot 9 \\
\text { Premenopausal: } 92 \cdot 6 \\
\text { Postmenopausal: } 89 \cdot 8\end{array}$ & $\begin{array}{l}90 \cdot 3 \text { to } 99 \cdot 3 \\
86 \cdot 9 \text { to } 96 \cdot 9 \\
83 \cdot 8 \text { to } 101 \cdot 4 \\
84 \cdot 2 \text { to } 95 \cdot 4\end{array}$ \\
\hline 30 & $41: 9$ & 62 & 8 & Not available & SPA & Radius, distal & $\begin{array}{l}\text { Women: } 88 \\
\text { Men: } 84\end{array}$ & $\begin{array}{l}82 \text { to } 96 \\
78 \text { to } 90\end{array}$ \\
\hline 31 & $51: 37$ & $51 \cdot 7$ & 4 & $\begin{array}{l}\text { I: } n=11 \\
\text { II: } n=62 \\
\text { III: } n=15\end{array}$ & QCT & Spine & $89 \cdot 4$ & $84 \cdot 8$ to $94 \cdot 0$ \\
\hline 16 & $44: 27$ & $56 \cdot 0$ & $10 \cdot 4$ & Not available & SPA & Radius, distal & $\begin{array}{l}\text { Premenopausal: } 111 \cdot 1 \\
\text { Postmenopausal } 97 \cdot 8 \\
\text { Men: } 97 \cdot 1\end{array}$ & $\begin{array}{l}99 \cdot 5 \text { to } 122 \cdot 7 \\
88 \cdot 3 \text { to } 107 \cdot 3 \\
90 \cdot 4 \text { to } 103 \cdot 8\end{array}$ \\
\hline 32 & $30: 14$ & $\begin{array}{l}\text { Women: } 56 \cdot 7 \\
\text { Men: } 54 \cdot 2\end{array}$ & $\begin{array}{l}\text { Women: } 12 \cdot 3 \\
\text { Men: } 10 \cdot 4\end{array}$ & $\begin{array}{l}\text { Women (HAQ): } 0.53 \\
\text { Men (HAQ): } 0.32\end{array}$ & QCT & $\begin{array}{l}\text { Spine, trabecular } \\
\text { Spine, cortical }\end{array}$ & $\begin{array}{l}\text { Women: } 99 \cdot 2 \\
\text { Men: } 111 \cdot 9 \\
\text { Women: } 106 \cdot 9 \\
\text { Men: } 109 \cdot 7\end{array}$ & $\begin{array}{l}87 \cdot 8 \text { to } 110 \cdot 6 \\
92 \cdot 9 \text { to } 130 \cdot 8 \\
98 \cdot 3 \text { to } 115 \cdot 4 \\
97 \cdot 3 \text { to } 122 \cdot 1\end{array}$ \\
\hline
\end{tabular}

${ }^{*}$ Functional capacity is evaluated with the Steinbrocker classification (class I, II, III, or IV), or if so indicated with a health assessment questionnaire (HAQ, range $0 \cdot 00-3 \cdot 00$ ). Higher classes or scores indicate more functional impairment.

†SPA = single photon absorptiometry; NA=neutron activation analysis; DPA=dual photon absorptiometry; QCT =quantitative computed tomography

decrease in mean bone mass in the lumbar spine and femoral neck $(96.9$ and $94.7 \%$ of normal respectively) when they compared 137 postmenopausal, non-steroid treated patients with RA with 739 controls. This difference disappeared, however, after further increasing the number of subjects in the study. Bone mass was also measured in 45 postmenopausal, glucocorticoid treated patients with RA. Prednisone was given in a mean daily dose of $6.4 \mathrm{mg}$, and the mean cumulative dose was $1.6 \mathrm{~g}$. The patients treated with prednisone had a significantly lower bone mass than those not treated, the difference being $6.5 \%$ in the lumbar spine and $8 \cdot 3 \%$ in the femoral neck. ${ }^{36}$

\section{LONGITUDINAL STUDIES}

Few longitudinal studies have been published so far. Sambrook et al compared 17 female nonglucocorticoid treated patients with recent onset RA with 19 controls matched for age and sex. They measured bone mass at the distal and proximal radius with quantitative computed tomography and at the lumbar spine with dual photon absorptiometry. In patients with RA bone loss was increased over one to two years at the distal radius only. ${ }^{37}$ The same investigators also measured changes in bone mass in the lumbar spine and the femoral neck with dual photon absorptiometry in 15 glucocorticoid treated and 15 non-glucocorticoid treated female patients with longstanding RA. The patients treated with glucocorticoids were already receiving prednisone before they entered the study, and the mean daily dose was $6.6 \mathrm{mg}$. A control group of 15 normal women matched for age was also included in this study. Baseline bone mass was significantly decreased in both the prednisone treated and untreated patients, but between these two groups no differences were found. Over a two year period rates of bone loss in patients with RA were normal, and no difference was seen between the prednisone treated and untreated patients. ${ }^{38}$ Reid et al measured changes in total body bone mass with neutron activation analysis over an 18 month period in 30 glucocorticoid treated and 34 untreated patients with RA. At the start of the study the mean duration of prednisone treatment was 4.7 years and the mean daily dose was 5.7 mg. Nineteen patients with primary generalised osteoarthrosis served as a control group. Baseline bone mass was significantly decreased in the non-glucocorticoid treated patients with RA, and even more in those treated with prednisone. Rates of bone loss were increased in the rheumatoid patients without glucocorticoid treatment, but normal in the patients treated with prednisone. ${ }^{24}$

Gough et al, who evaluated bone mass with dual energy $x$ ray absorptiometry, recently reported significant bone loss over a one year period occurring in patients with early RA. Of 52 patients, 13 lost bone at the lumbar spine and 15 at the femoral neck. ${ }^{39} \mathrm{We}$, ourselves, reported the preliminary results of a randomised controlled trial, in which 40 patients with active RA who started treatment with intramuscular gold salts were randomly allocated to receive either low dose prednisone or placebo. The patients treated with prednisone showed a significant reduction in trabecular lumbar bone mass after a period of only 20 weeks, whereas bone mass remained unchanged in patients receiving placebo. ${ }^{40}$ Laoussadi et al reported the results of a randomised controlled trial that compared the effects of $1 \mathrm{~g}$ methylprednisolone given intravenously once every two months with the effects of $16 \mathrm{mg}$ methylprednisolone taken orally each day. The patients receiving oral treatment showed a significant decrease in lumbar bone 
Table 3 Bone mass in glucocorticoid treated patients with rheumatoid arthritis: cross sectional studies

\begin{tabular}{|c|c|c|c|c|c|c|}
\hline \multirow[t]{3}{*}{$\operatorname{Ref}$} & \multirow{3}{*}{$\begin{array}{l}\text { Number } \\
\text { (women:men) }\end{array}$} & \multicolumn{5}{|c|}{ Patient characteristics } \\
\hline & & \multirow[t]{2}{*}{ Age (years) } & \multirow{2}{*}{$\begin{array}{l}\text { Duration of } \\
R A \text { (years) }\end{array}$} & \multirow{2}{*}{$\begin{array}{l}\text { Functional capacity } \\
(F C)^{*}\end{array}$} & \multicolumn{2}{|c|}{ Glucocorticoidst } \\
\hline & & & & & Dose & Duration \\
\hline 27 & $22: 9$ & Women: $56 \cdot 1$ & $12 \cdot 3$ & 2.00 & $6 \cdot 3$ & $6 \cdot 6$ \\
\hline 15 & 44:31 & $\begin{array}{l}\text { Men: } 53 \cdot 6 \\
51 \cdot 7\end{array}$ & $\begin{array}{r}5 \cdot 7 \\
10 \cdot 4\end{array}$ & $\begin{array}{l}1.89 \\
\text { Not available }\end{array}$ & $\begin{array}{l}6 \cdot 1 \\
7 \cdot 1\end{array}$ & $\begin{array}{l}2 \cdot 7 \\
6 \cdot 1\end{array}$ \\
\hline 17 & 44:10 & $\begin{array}{l}\text { Pre: } 46 \cdot 2 \\
\text { Post: } 67 \cdot 6 \\
\text { Men: } 56 \cdot 7\end{array}$ & $\begin{array}{l}15 \cdot 1 \\
14 \cdot 5 \\
15 \cdot 6\end{array}$ & $\begin{array}{l}2 \cdot 6 \\
2 \cdot 4 \\
2 \cdot 2\end{array}$ & $\begin{array}{l}7 \cdot 6 \\
8.3 \\
7.9\end{array}$ & $\begin{array}{r}8 \cdot 4 \\
5 \cdot 6 \\
10 \cdot 2\end{array}$ \\
\hline 28 & 28:0 & $59 \cdot 2$ & $17 \cdot 7$ & $\begin{array}{l}\text { II: } n=11 \\
\text { III: } n=16\end{array}$ & 8.9 & $4 \cdot 7$ \\
\hline 29 & 44:0 & $56 \cdot 2$ & $14 \cdot 7$ & $\begin{array}{l}\text { IV: } n=1 \\
\text { I: } n=7 \\
\text { II: } n=27 \\
\text { III: } n=10\end{array}$ & $8 \cdot 0$ & $7 \cdot 5$ \\
\hline 16 & 44:27 & $56 \cdot 5$ & $11 \cdot 7$ & Not available & $\begin{array}{l}\text { Pre: } 4 \cdot 2 \\
\text { Post: } 4 \cdot 3 \\
\text { Men: } 5 \cdot 0\end{array}$ & $\begin{array}{l}4 \cdot 0 \\
5 \cdot 4 \\
5 \cdot 2\end{array}$ \\
\hline 32 & $16: 14$ & $\begin{array}{l}\text { Women: } 61 \cdot 2 \\
\text { Men: } 68 \cdot 6\end{array}$ & $\begin{array}{l}18 \cdot 8 \\
10 \cdot 4\end{array}$ & $\begin{array}{l}\text { HAQ: } 1.08 \\
\text { HAQ: } 0.50\end{array}$ & & $\begin{array}{l}7.9 \\
4 \cdot 2\end{array}$ \\
\hline
\end{tabular}

\begin{tabular}{|c|c|c|c|c|c|c|}
\hline \multirow[t]{3}{*}{ Ref } & \multicolumn{6}{|c|}{ Bone mass } \\
\hline & \multirow[t]{2}{*}{ Method $\neq$} & \multirow[t]{2}{*}{ Site } & \multicolumn{2}{|c|}{ Results (percentage of normal) } & \multicolumn{2}{|c|}{ Prednisone influenceS } \\
\hline & & & Mean & $95 \%$ CI limits & Mean & $95 \%$ CI limits \\
\hline 27 & NA & Total body & $\begin{array}{l}\text { Women: } 85 \\
\text { Men: } 90\end{array}$ & $\begin{array}{l}80 \text { to } 90 \\
83 \text { to } 97\end{array}$ & $\begin{array}{l}-9 \\
-5\end{array}$ & $\begin{array}{l}-15 \text { to }-3 \\
-13 \text { to }+3\end{array}$ \\
\hline 15 & SPA & Radius, proximal & $89 \cdot 7$ & $86 \cdot 1$ to 93.3 & $-5 \cdot 9$ & -11.0 to -0.8 \\
\hline & & Radius, distal & $84 \cdot 3$ & $79 \cdot 9$ to $88 \cdot 7$ & $-8 \cdot 6$ & $-14 \cdot 9$ to $-2 \cdot 3$ \\
\hline 17 & SPA & Radius, distal & $\begin{array}{l}\text { Pre: } 70 \\
\text { Post: } 90 \\
\text { Men: } 73\end{array}$ & $\begin{array}{l}60 \text { to } 80 \\
80 \text { to } 100 \\
59 \text { to } 87\end{array}$ & $\begin{array}{l}-23 \\
+10\end{array}$ & $\begin{array}{l}-38 \text { to }-8 \\
-6 \text { to }+26\end{array}$ \\
\hline & DPA & Total body & $\begin{array}{l}\text { Pre: } 78 \\
\text { Post: } 77\end{array}$ & $\begin{array}{l}70 \text { to } 86 \\
71 \text { to } 83\end{array}$ & $\begin{array}{l}-14 \\
-20 \\
-1\end{array}$ & $\begin{array}{l}-31 \text { to }-9 \\
-315 \text { to }+13\end{array}$ \\
\hline & & & Men: 77 & 71 to 83 & -18 & -28 to -8 \\
\hline 28 & SPA & $\begin{array}{l}\text { Radius, proximal } \\
\text { Radius, distal }\end{array}$ & $\begin{array}{l}88.1 \\
91 \cdot 5\end{array}$ & $\begin{array}{l}77.4 \text { to } 98 \cdot 8 \\
84.4 \text { to } 98 \cdot 6\end{array}$ & $\begin{array}{l}+3 \cdot 7 \\
+4 \cdot 3\end{array}$ & $\begin{array}{l}-8 \cdot 4 \text { to }+15 \cdot 8 \\
-4 \cdot 5 \text { to }+13 \cdot 1\end{array}$ \\
\hline & DPA & Spine & 95.9 & 85.9 to 105.9 & $-13 \cdot 5$ & $-25 \cdot 4$ to -1.6 \\
\hline 29 & DPA & $\begin{array}{l}\text { Spine } \\
\text { Femoral neck }\end{array}$ & $\begin{array}{l}\text { Pre: } 94.9 \\
\text { Post: } 88.5 \\
\text { Pre: } 88.6\end{array}$ & $\begin{array}{l}81 \cdot 6 \text { to } 107 \cdot 3 \\
84 \cdot 3 \text { to } 92 \cdot 7 \\
71 \cdot 0 \text { to } 106 \cdot 2\end{array}$ & $\begin{array}{l}-0 \cdot 1 \\
-3 \cdot 4 \\
-4 \cdot 0\end{array}$ & $\begin{array}{l}-13 \cdot 4 \text { to }+13 \cdot 2 \\
-9 \cdot 9 \text { to }+3 \cdot 1 \\
-15 \cdot 7 \text { to }+7 \cdot 7\end{array}$ \\
\hline 16 & SPA & Radius, distal & $\begin{array}{l}\text { Post: } 82 \cdot 4 \\
\text { Pre: } 111 \cdot 1 \\
\text { Post: } 81 \cdot 7 \\
\text { Men: } 85 \cdot 3\end{array}$ & $\begin{array}{l}77 \cdot 4 \text { to } 87 \cdot 4 \\
92 \cdot 1 \text { to } 130 \cdot 1 \\
72 \cdot 6 \text { to } 90 \cdot 8 \\
76 \cdot 9 \text { to } 93 \cdot 7\end{array}$ & $\begin{array}{l}-7 \cdot 4 \\
0 \\
-16 \cdot 1 \\
-11 \cdot 8\end{array}$ & $\begin{array}{l}-14 \cdot 9 \text { to }+0 \cdot 1 \\
-21 \cdot 0 \text { to }+21 \cdot 0 \\
-29 \cdot 1 \text { to }-3 \cdot 1 \\
-22 \cdot 3 \text { to }-1 \cdot 3\end{array}$ \\
\hline 32 & QCT & $\begin{array}{l}\text { Spine, trabecular } \\
\text { Spine, cortical }\end{array}$ & $\begin{array}{l}\text { Women: } 65 \cdot 0 \\
\text { Men: } 101 \cdot 4 \\
\text { Women: } 75 \cdot 5 \\
\text { Men: } 103 \cdot 6\end{array}$ & $\begin{array}{l}55 \cdot 6 \text { to } 74 \cdot 4 \\
84 \cdot 1 \text { to } 118 \cdot 7 \\
68 \cdot 7 \text { to } 82 \cdot 2 \\
83 \cdot 0 \text { to } 124 \cdot 1\end{array}$ & $\begin{array}{l}-31 \cdot 2 \\
-10 \cdot 5 \\
-37 \cdot 2 \\
-6 \cdot 1\end{array}$ & $\begin{array}{l}-50.3 \text { to }-12.1 \\
-34.9 \text { to }+13.9 \\
-53.6 \text { to }-20.8 \\
-28.9 \text { to }+16.7\end{array}$ \\
\hline
\end{tabular}

${ }^{*}$ Functional capacity is evaluated with the Steinbrocker classification (class I, II, III, or IV), or if so indicated with a health assessmen questionnaire (HAQ, range $0 \cdot 00-3 \cdot 00$ ). Higher classes or scores indicate more functional impairment.

TThe mean dose represents milligrams prednisone equivalents/day. The mean duration of treatment is given in years.

¥SPA=single photon absorptiometry; NA=neutron activation analysis; DPA=dual photon absorptiometry; $Q C T=q u a n t i t a t i v e$ computed tomography.

$\S$ Represents the difference between glucocorticoid treated and untreated patients, expressed as percentage from bone mass in untreated patients.

patients.
Pre = premenopausal; Post $=$ postmenopausal.

mass of about $10 \%$ after two months of treatment, with no further losses in the next four months. In patients receiving intravenous pulse therapy bone mass did not change. ${ }^{41}$

\section{Determinants of bone mass in patients with RA}

Some studies have attempted to identify determinants of bone mass in patients with $R A$, mostly by calculating correlation coefficients between bone mass and a single suspected determinant. As bone mass in patients with RA will probably be influenced by more than one factor at the same time, such simple analyses are of limited value only. Other studies have used multivariate techniques that allow the simultaneous evaluation of several possible determinants. ${ }^{1733394243}$
RISK FACTORS FOR RA RELATED BONE LOSS

Generalised osteoporosis may be an extraarticular manifestation of RA, and some disease related factors have been suggested as possible risk factors for increased bone loss. These include disease duration, reduced mobility, and disease activity. Some have also suggested that the risk of RA related bone loss is associated with age and menopausal state.

\section{Age and menopausal state}

In some studies the bone mass corrected for age was smaller in postmenopausal than in premenopausal patients with RA, though the differences were not always statistically significant. ${ }^{16} 1729$ These observations seem to indicate that deleterious effects of RA on bone mass may be somewhat accentuated postmeno- 
pausally. In contrast, Compston et al suggested that $\mathrm{RA}$ related bone loss occurs mainly in younger patients with RA. ${ }^{31}$

\section{Duration of disease}

If disease related mechanisms are responsible for bone loss in patients with RA, one might expect bone mass to be correlated with disease duration. In patients with longstanding RA such correlations have, however, not been shown in most studies. ${ }^{16273134}$ Als et al stratified 105 non-glucocorticoid treated patients with RA in three subgroups according to the duration of disease: $0-3,4-8$, and more than 8 years. Their data indicated that RA related mechanisms for bone loss may be more important in the first years of the disease. ${ }^{23}$ Further support for this hypothesis came from a recent study in our department. With multivariate techniques we showed that bone mass in the lumbar spine and the femoral neck is related to disease duration in rheumatoid patients with disease durations varying between three months and five years. ${ }^{43}$

\section{Reduced mobility}

The level of weightbearing activity may be an important determinant of bone mass. Extreme inactivity causes rapid loss of considerable amounts of bone, and most exercise intervention programmes have shown either a reduction in bone loss or an increase in bone mass. ${ }^{22} 4445$

Sambrook et al showed that the level of physical activity, as measured with the Framingham activity index, is correlated with axial bone mass in patients with RA. In a multiple linear regression analysis in female patients this association persisted for the femoral neck, but not the lumbar spine. Parameters of disease activity were, however, not included among the variables considered in the analysis. ${ }^{33}$

Functional capacity, evaluated with either the Steinbrocker classification or more recently with health assessment questionnaires, has also been considered as a possible determinant of bone mass in patients with RA. Als et al stratified 105 non-glucocorticoid treated patients with RA in three subgroups according to their functional class: I, II, and III/IV. The lowest bone mass was found in the patients with the greatest functional impairment. It should be noted that the three subgroups also showed significant differences in disease duration. ${ }^{23}$ Using multiple linear regression analysis we recently showed that femoral bone mass is negatively associated with functional impairment in patients with early RA. ${ }^{43}$ In a prospective study Gough et al, who also used multivariate techniques, showed that patients with more functional impairment were more at risk for femoral bone loss. ${ }^{39}$

\section{Disease activity}

Several cytokines have been implicated as pathogenetic factors in patients with active RA. ${ }^{46}$ Some of these are also known to influence bone cells. Interleukin 1 and tumour necrosis factor are among the strongest stimulators of osteoclasts, and interleukin 1 has been suggested as a pathogenetic factor in patients with primary osteoporosis and high bone turnover. ${ }^{47} 48$

The evidence linking disease activity to bone loss in patients with RA is as yet limited. Sambrook showed a significant correlation between serum concentrations of $\mathrm{C}$ reactive protein and the rate of lumbar bone loss in patients with recent onset RA. ${ }^{37}$ With multivariate techniques we showed an association between bone mass in the femoral neck and the erythrocyte sedimentation rate also in patients with early RA. Some other parameters of disease activity were not related to bone mass. ${ }^{43}$ Gough et al showed that patients with recent onset $R A$ with higher serum $C$ reactive protein concentrations were more at risk for lumbar bone loss. ${ }^{39}$

\section{INFLUENCE OF ANTIRHEUMATIC TREATMENT} ON BONE MASS

Patients with RA are treated with a variety of drugs, some of which may affect bone mass.

Non-steroidal anti-inflammatory drugs inhibit bone formation and resorption in in vitro experiments and in laboratory animals. ${ }^{49} 50 \mathrm{In}$ patients with primary osteoarthrosis of the hip it has been suggested that these drugs may be associated with acetabular bone destruction. ${ }^{51}$ No studies are available to suggest their involvement in the pathogenesis of generalised bone loss in patients with RA.

Disease modifying antirheumatic drugs may also affect bone metabolism. In vitro, gold salts inhibit osteoclastic bone resorption. ${ }^{52}$ It has been reported that some disease modifying antirheumatic drugs may reverse metacarpal bone loss in patients with active RA. ${ }^{53}$

\section{RISK FACTORS FOR GLUCOCORTICOID INDUCED} BONE LOSS

The effects of glucocorticoids on bone and the pathogenesis of prednisone induced osteoporosis have been reviewed extensively. In short, glucocorticoids have both direct and indirect effects on bone. They inhibit bone formation and increase bone resorption, and cause osteoporosis in patients with various primary diseases. ${ }^{54-57}$ The effect of low dose glucocorticoid treatment on bone mass in patients with RA is controversial, as was discussed before.

Not all patients treated with glucocorticoids will lose bone at an increased rate, which may partly explain the reported discrepancies. Dykman et al have shown that about $40 \%$ of patients treated with prednisone have increased ratios of diaphysial to metaphysial bone mass in the forearm. ${ }^{42}$ This finding has been suggested as a specific marker of glucocorticoid induced osteopenia. ${ }^{58}$ The factors that determine the individual susceptibility to the effects of glucocorticoids on bone have not been fully defined.

Age, sex, and menopausal state

Deleterious effects of low dose prednisone treatment have been reported in both female ${ }^{15-17}$ 273236 and male $15-1733$ patients with RA. 
Premenopausal patients with RA were found to be at increased risk in one study, ${ }^{17}$ whereas in two other studies postmenopausal patients were more likely to be affected by low dose glucocorticoid treatment. ${ }^{1516}$ Age over 50 has also been suggested as a risk factor for glucocorticoid-induced bone loss in male patients with RA. ${ }^{15}$

Dykman et al studied the diaphysial to metaphysial bone mass ratio in the forearm in 161 patients with diverse rheumatic diseases receiving long term glucocorticoid treatment. ${ }^{42}$ By multivariate techniques they were unable to show that sex, age, or menopausal state influenced the prevalence of increased ratios, though fractures were more common in postmenopausal women and in patients aged 50 or over.

\section{Characteristics of treatment}

The patients in the study of Dykman et al were treated with a daily prednisone dose ranging from 1 to $80 \mathrm{mg}$ for one month to 25 years. The cumulative dose ranged from 0.2 to $118.5 \mathrm{~g}$. By multivariate techniques they showed a significant influence of cumulative, but not daily, dose on the prevalence of both an increased diaphysial to metaphysial bone mass ratio and fractures. ${ }^{42}$ No such associations were found in most studies of patients with RA treated with low dose prednisone, in whom cumulative doses were much smaller. ${ }^{17} 27283334$

The risk of glucocorticoid induced bone loss is probably similar in patients receiving daily and alternate day treatment. ${ }^{4259}$

\section{Bone sparing glucocorticoids}

Deflazacort, a new oxazoline derivative of prednisone, may have less influence on bone than prednisone in dosages with a similar antiinflammatory action. ${ }^{546061}$

\section{Fractures in patients with RA}

Bone mass is an important factor in the pathogenesis of fractures. If bone loss occurs in patients with RA an increased risk of fractures may be expected. Fracture incidence has been shown to be moderately increased in patients with RA. The relative risk for fracture in RA is about 1.5 to $2.5 .{ }^{62} 63$ The risk is increased especially for pelvic and hip fractures. ${ }^{62}$ A diagnosis of osteoporosis before the development of RA, and prednisone treatment in a dose of more than $5 \mathrm{mg} /$ day, may be associated with an additional increase in fracture risk. ${ }^{64}$ Current use of corticosteroids did not significantly influence fracture risk in two other studies. ${ }^{62} 63$ Impaired mobility and a low body mass index have also been stressed as important predisposing factors for fractures. ${ }^{62} 63$

\section{Concluding remarks}

In this review we have summarised the most recent reports on the association between decreased bone mass and RA. Some data have as yet only been published in abstracts, and full length reports should be awaited before drawing definite conclusions.

The available data seem to indicate that generalised osteoporosis may indeed be an extra-articular manifestation of RA, occurring in a subset of patients. The disease is probably associated with a small decrease in mean bone mass, which was not statistically significant in all studies, and with a moderate increase in fracture risk. Recent studies suggest that bone mass may be affected by disease dependent factors, such as functional impairment and the activity of the inflammatory process itself, especially early in the course of RA. Long term follow up studies are needed to understand better the changes in bone mass in patients with longstanding RA, but the present data suggest impaired mobility as an important determinant of both bone loss and fractures throughout the course of the disease.

The influence of prednisone treatment on bone mass has been evaluated in patients with RA. Some cross sectional studies showed significant negative associations between bone mass and low dose prednisone treatment, whereas other studies did not show significant differences. As the $95 \%$ confidence intervals for the difference between prednisone treated and untreated patients are mostly rather broad, deleterious effects of prednisone treatment are not excluded in the negative studies. In longitudinal studies no increased bone loss has been shown in patients who had received glucocorticoid treatment for several years, but significant bone loss has recently been shown early in the course of treatment, even when low doses are used. Further prospective studies are urgently needed to understand better the long term effects of low dose glucocorticoids on bone mass. They may also help to characterise better the factors that determine the individual susceptibility to glucocorticoid induced osteoporosis in patients with RA.

1 Bijlsma J W J. Bone metabolism in patients with rheumatoid arthritis. Clin Rheumatol 1988; 7: 16-23.

Sambrook P N, Reeve J. Bone disease in rheumatoid arthritis. Clin Sci 1988; 74: 225-30.

3 Dequeker J, Geusens P. Osteoporosis and arthritis. Ann Rheum Dis 1990; 49: 276-80.

4 Woolf A D. Osteoporosis in rheumatoid arthritis-the clinical viewpoint. Br 7 Rheumatol 1991; 30: 82-4

5 Peel N F A, Eastell R, Russell R G G. Osteoporosis in rheumatoid arthritis-the laboratory perspective. $\mathrm{Br} \mathcal{J}$ Rheumatol 1991; 30: 84-5.

6 Joffe I, Epstein S. Osteoporosis associated with rheumatoid arthritis: pathogenesis and management. Semin Arthritis Rheum 1991; 20: 256-72.

7 Caldwell J R, Furst D E. The efficacy and safety of low-dose corticosteroids for rheumatoid arthritis. Semin Arthritis Rheum 1991; 21: 1-11.

8 Conference report. Consensus development conference: prophylaxis and treatment of osteoporosis. Am f Med 1991; 90: $107-10$

9 Genant H K, Ettinger B, Harris S T, Block J E, Steiger P. Quantitative computed tomography in assessment of osteoporosis. In: Riggs B L, Melton L J III, eds. Osteoporosis: etiology, diagnosis, and management. New York: Raven Press, 1988: 221-49.

10 Mazess R B, Wahner H M. Nuclear medicine and densitometry. In: Riggs B L, Melton L J III, eds. Osteoporosis: etiology, diagnosis, and management. New York: Raven etiology, diagnosis, and

11 Genant H K, Steiger P, Faulkner K G, Majumdar S, Lang P Glüer C C. Non-invasive bone mineral analysis: recent advances and future directions. In: Christiansen $\mathrm{C}$, Overgaard K, eds. Osteoporosis 1990. Copenhagen: Osteo-

12 Johnston G C, Slemenda C W, Melton L J III. Clinical use of bone densitometry. $N$ Engl $\mathcal{J}$ Med 1991; 324: 1105-9. 
13 Richardson M L, Genant H K, Cann C E, et/al. Assessment of metabolic bone diseases by quantitative computed tomography. Clin Orthop Relat Res 1985; 195: 224-38.

14 Riggs B L, Wahner H W, Dunn W L, Mazess R B, Offord $\mathrm{K} \mathrm{P}$, Melton L J III. Differential changes in bone mineral density of the appendicular and axial skeleton with aging f Clin Invest 1981; 67: 328-35.

15 Nagant de Deuxchaisnes C, Devogelaer J P, Esselinckx W, et al. The effect of low dosage glucocorticoids on bone mass in rheumatoid arthritis: a cross-sectional and a longitudinal reumatoid arthritis: a cross-sectional and a longitudina study using single photo

16 Butler R C, Davie M W J, Worsfold M, Sharp C A. Bone mineral content in patients with rheumatoid arthritis: relationship to low-dose steroid therapy. $\mathrm{Br} \mathcal{F}$ Rheumato 1991; 30: 86-90.

17 Als O S, Gotfredsen A, Christiansen C. The effect of glucocorticoids on bone mass in rheumatoid arthritis patients. Influence of menopausal state, Arthritis Rheum 1985; 28: 369-75.

18 Ross P D, Davis W D, Vogel J M, Wasnich R D. A critica review of bone mass and the risk of fractures in osteoporosis. Calcif Tissue Int 1990; 46: 149-61.

19 Ross P D, Davis J W, Epstein R S, Wasnich R D. Preexisting fractures and bone mass predict vertebral fracture
incidence in women. Ann Intern Med 1991; 114: 919-23.

20 Mellish R W E, O'Sullivan M M, Garrahan N J, Compston $J$ E. Iliac crest trabecular bone mass and structure in patients with rheumatoid arthritis. Ann Rheum Dis 1987 46: $830-6$.

21 Stellon A J, Webb A, Compston J E. Bone histomorphometry and structure in corticosteroid-treated active hepatitis. Gut 1988; 29: 378-84

22 Cummings S R, Kelsey J L, Nevitt M C, O'Dowd K J Epidemiology of osteoporosis and osteoporotic fractures. Epidemiol Rev 1985; 7: 178-208.

23 Als O S, Gotfredsen A, Riis B, Christiansen C. Are disease duration and degree of functional impairment determinants of bone loss in rheumatoid arthritis? Ann Rheum Dis 1985; 44: 406-11.

24 Reid D M, Kennedy N S J, Smith M A, et al. Bone loss in rheumatoid arthritis and primary generalized osteoarthrosis: effects of corticosteroids, suppressive antirheumatic drugs

25 LoCascio V, Bonucci E, Imbimbo B, et al. Bone loss in response to long term glucocorticoid therapy. Bone Miner 1990; 8: 39-51.

26 Oka M, Rekonen A, Kuikka J, Anttinen J. Bone minera density in rheumatoid arthritis measured by the gamma transmission method. Scand F Rheumatol 1975; 4: 28-32.

27 Reid D M, Kennedy N S J, Smith M A, Tothill P, Nuki G. Total body calcium in rheumatoid arthritis: effects of disease activity and corticosteroid treatment. BMF 1982 285: $330-2$.

28 Vertraeten A, Dequeker J. Vertebral and peripheral bone mineral content and fracture incidence in postmenopausal patients with rheumatoid arthritis: effect of low dose patients with rheumatoid arthritis: effect of
corticosteroids. Ann Rheum Dis 1986; 45: 852-7

29 Sambrook P N, Eisman J A, Yeates M G, Pocock N A, Eber $S$, Champion G D. Osteoporosis in rheumatoid arthritis: S, Champion G D. Osteoporosis in rheumatoid arthritis: safety of

30 Cooper C, Poll V, McLaren M, Daunt S O'N, Cawley M I D. Alterations in appendicular skeletal mass in patients with rheumatoid, psoriatic, and osteoarthropathy. Ann Rheum Dis 1988; 47: 481-4.

31 Compston J E, Crawley E O, Evans C, O'Sullivan M M Spinal trabecular bone mineral content in patients with non-steroid treated rheumatoid arthritis. Ann Rheum $D$ is 1988; 47: $660-4$.

32 Laan R F J M, van Riel P L C M, van Erning L J Th O, Lemmens J A M, Ruijs S H J, van de Putte L B A. Vertebral osteoporosis in rheumatoid arthritis patients: effect of low dose prednisone therapy. $B r \not R$ Reumatol 1992; 31: 91-6.

33 Sambrook P N, Eisman J A, Champion G D, Yeates M G Pocock N A, Eberl S. Determinants of axial bone loss in
rheumatoid arthritis. Arthritis Rheum 1987; 30: 721-8.

34 O'Malley M, Kenrick A J, Sartoris D J, et al. Axial bone density in rheumatoid arthritis: comparison of dual-energy projection radiography and dual-photon absorptiometry. Radiology 1989; 170: 501-5.

35 Eggelmeijer F, Camps J A J, Valkema R, et al. Lumbar bone mineral density in rheumatoid arthritis: normal values in ambulant, non-steroid treated patients. $\mathrm{Br} \mathcal{J}$ Rheumatol 1991; 30 (suppl 2): 53

36 Hall G M, Hall M L, Ell P J, Doyle D V, Spector T D. Bone density of the hip and spine in postmenopausal rheumatoid
arthritis (RA) and the effect of low dose steroids. $\mathrm{Br} \mathcal{J}$ Rheumatol 1991; 30 (suppl 2): 53.

37 Sambrook P N, Ansell B M, Foster S, Gumpel J M, Hesp R,
Reeve J. Bone turnover in early rheumatoid arthritis. 2 Longitudinal bone density studies. Ann Rheum Dis 1985 44: $580-4$.

38 Sambrook P N, Cohen M L, Eisman J A, Pocock N A Champion G D, Yeates M G. Effects of low dose corticosteroids on bone mass in rheumatoid arthritis: longitudinal study. Ann Rheum Dis 1989; 48: 535-8.

39 Gough A, Lilley J, Ayre S, Sheeran T, Emery P. Axial bone loss in early rheumatoid arthritis-an association with loss in early rheumatoid arthritis-an associatic

40 Laan R, van Riel P, van Erning L, Lemmens A, Ruijs S, van de Putte L. Short term effect of low dose prednisone therapy on bone mineral density in patients with rheumatoid arthritis. Arthritis Rheum 1991; 34: $\$ 90$.

41 Laoussadi S, Bauer-Vinassac D, Galimard E, Menkes C J. Effect of corticosteroid therapy on bone mineral conten (BMC) in rheumatoid arthritis (RA). Arthritis Rheum 1991 34: S127.

42 Dykman T R, Gluck O S, Murphy W A, Hahn T J, Hahn $B$ H. Evaluation of factors associated with glucocorticoidinduced osteopenia in patients

43 Laan R, Buijs W, Draad M, et al. Bone mineral density in rheumatoid arthritis (RA): influence of disease activity and rheumatoid arthritis (RA): influence of disease activity
functional capacity. Arthritis Rheum 1991; 34: S180.

44 Smith E L, Gilligan C. Physical activity effects on bone metabolism. Calcif Tissue Int 1991; 49: S50-4.

45 Gerber N J, Rey B. Can exercise prevent osteoporosis? Br $\mathcal{J}$ Rheumatol 1991; 30: 2-4.

46 Arend W P, Dayer J-M. Cytokines and cytokine inhibitors or antagonists in rheumatoid arthritis. Arthritis Rheum 1990 33: 305-15.

47 Peck W A, Woods W L. The cells of bone. In: Riggs B L Melton L J III, eds. Osteoporosis: etiology, diagnosis, and management. New York: Raven Press, 1988: 1-44.

48 Pacifici R, Rifas L, Teitelbaum S, et al. Spontaneous release of interleukin 1 from human blood monocytes reflects bone formation in idiopathic

49 Lerner $U$. Indomethacin inhibits bone resorption and lysosomal enzyme release from bone in organ culture. Scand f Rheumatol 1980; 9: 149-56.

50 Lindholm $T S$, Törnkvist $H$. Inhibitory effect on bone formation and calcification exerted by the anti-inflammatory drug ibuprofen. Scand F Rheumatol 1981; 10: 38-42.

51 Newman N M, Ling R S M. Acetabular bone destruction related to non-steroidal anti-inflammatory drugs. Lance 1985; i: 11-14.

52 Vargas S J, Jones T G, Hurley M M, Raiš L G. Comparison of the effects of auranofin, gold sodium thiomalate, and penicillamine on resorption of cultured fetal rat long bones. f Bone Miner Res 1987; 2: 183-9.

53 Kalla A A, Meyers O L, Chalton D, et al. Increased metacarpal bone mass following 18 months of slow-acting antirheumatic drugs for rheumatoid arthritis. $\mathrm{Br} \mathcal{Y}$ Rheumatol 1991; 30: 91-100.

54 Baylink D J. Glucocorticoid-induced osteoporosiss. $N$ Engl 7 Med 1983; 309: 306-8.

55 Reid I R. Pathogenesis and treatment of steroid osteoporosis Clin Endocrinol (OxJ) 1989; 30: 83-103.

56 Bockman R S, Weinerman S A. Steroid-induced osteoporosis. Orthop Clin North Am 1990; 21: 97-107.

57 Lukert B P, Raisz L G. Glucocorticoid-induced osteoporosis: pathogen

58 Hahn T J, Boisseau V C, Avioli L V. Effect of chronic corticosteroid administration on diaphyseal and metaphyseal bone mass. I Clin Endocrinol Metab 1974; 39. physeal

59 Gluck O S, Murphey W A, Hahn T J, Hahn B. Bone loss in adults receiving alternate day glucocorticoid therapy. A comparison with daily therapy. Arthritis Rheum 1981;24: 892-8.

60 Gennari C, Imbimbo B, Montagnani M, Bernini M, Nardi P, Avioli L V. Effects of prednisone and deflazacort on mineral metabolism and parathyroid hormone activity in humans. Calcif Tissue Int 1984; 36: 245-52.

61 Gray $\bar{R} \bar{E} \bar{S}$, Doherty $\bar{S} \bar{M}$, Galloway J, Coulton L, de Broe M, Kanis J A. A double-blind study of deflazacort and prednisone in patients with chronic inflammatory disorders. prednisone in patients with chronic in
Arthritis Rheum 1991; 34: 287-95.

62 Hooyman J R, Melton L J III, Nelson A M, O'Fallon W M Riggs B L. Fractures after rheumatoid arthritis. A populatio based study. Arthritis Rheum 1984; 27: 1353-61

63 Cooper C, Wickham C. Rheumatoid arthritis, corticosteroid therapy and hip fracture. In: Christiansen C, Overgaard K eds. Osteoporosis 1990. Copenhagen: Osteopress, 1990 1578-9.

64 Michel B A, Bloch D A, Fries J F. Predictors of fractures in early rheumatoid arthritis. $\mathcal{F}$ Rheumatol 1991; 18: 804-8. 